\title{
Table of EU Regulations
}

Regulation 1612/68 on the free movement of workers, amended by Regulation 312/76/EEC and Regulation 2434/92/EEC

Regulation 1251/70 on the right to remain in the host Member State

Regulation 1408/71 Social Security Regulation

EC Merger Regulations, 1986

Regulation 2157/2001 Regulation for a European Company Statute 